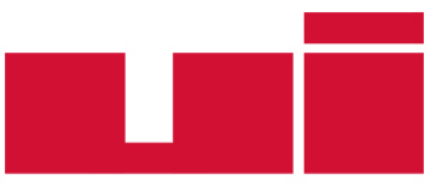

$\underset{\substack{\text { ULLUSLARARASSilisişKiLER } \\ \text { Akademik Dergi }}}{\text { D. }}$

Yayın ilkeleri, izinler ve abonelik hakkında ayrıntılı bilgi:

E-mail: bilgi@uidergisi.com.tr

Web: www.uidergisi.com.tr

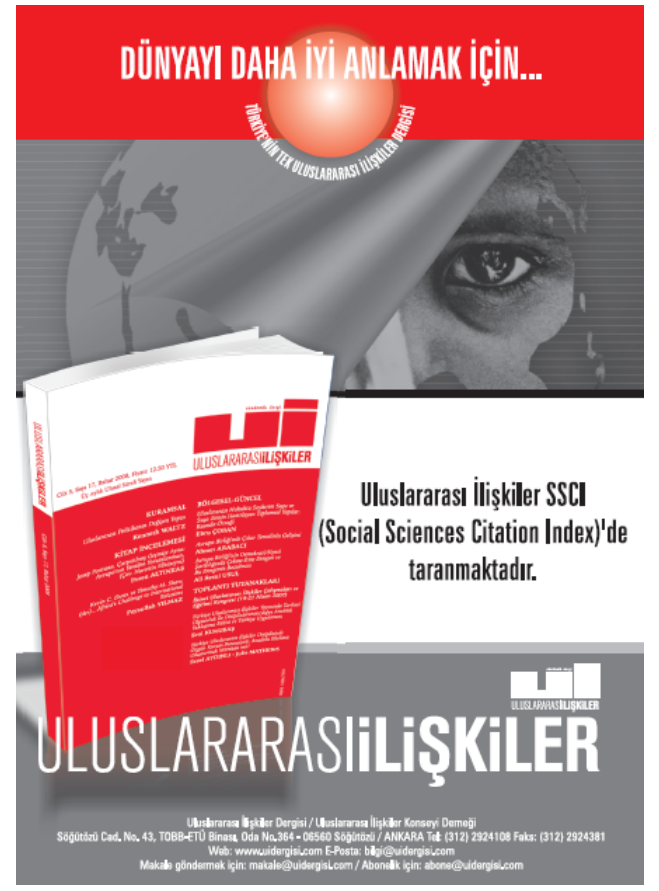

\title{
Diplomasi Tarihinin Ötesi: Uluslararası İlişkiler Tarih Yazımında Fransız Ekolï
}

\author{
Ateş USLU* \\ * Yrd. Doç. Dr., İstanbul Üniversitesi,
} Siyaset Bilimi ve Uluslararası İlişkiler Bölümü

Bu makaleye atıf için: Uslu, Ateş, "Diplomasi Tarihinin Ötesi: Uluslararası İlişkiler Tarih Yazımında Fransız Ekolü", Uluslararası İlişkiler, Cilt 11, Sayı 44 (Kış 2015), s. 25-49.

Bu makalenin tüm hakları Uluslararası İlișkiler Konseyi Derneği'ne aittir. Önceden yazılı izin alınmadan hiç bir iletişim, kopyalama ya da yayın sistemi kullanılarak yeniden yayımlanamaz, çoğaltılamaz, dağıtılamaz, satılamaz veya herhangi bir şekilde kamunun ücretli/ücretsiz kullanımına sunulamaz. Akademik ve haber amaçlı kısa alıntılar bu kuralın dışındadır.

Aksi belirtilmediği sürece Uluslararası Illişkiler'de yayınlanan yazılarda belirtilen fikirler yalnızca yazarına/yazarlarına aittir. UIKK Derneğini, editörleri ve diğer yazarları bağlamaz. 


\title{
Diplomasi Tarihinin Ötesi: Uluslararası İlişkiler Tarih Yazımında Fransız Ekolü
}

\author{
Ateş USLU*
}

\section{ÖZET}

Fransız tarihçi Pierre Renouvin, Birinci Dünya Savaşı'nı izleyen dönemde yayımladığı çalışmalarında uluslararası ilişkiler tarih yazımına yeni açılımlar getirmiştir. Renouvin, diplomatik olayları incelerken toplumsal, iktisadi, kültürel faktörleri göz önünde bulundurmaktadır. Renouvin'in etkisinde eser veren Jean-Baptiste Duroselle ve René Girault gibi tarihçiler de bu çalışmaları devam ettirmişlerdir. Fransız uluslararası ilişkiler tarihi ekolü mensupları devlet merkezli olmayan bir yaklaşım benimsemeye çalışsalar da devletin son aşamada belirleyici olduğundan hareket ederek tahlil yaparlar. Özelden hareketle tikele ve genele ulaşan bir yaklaşım benimserler. Fransız uluslararası ilişkiler ekolü mensupları geleceğe yönelik herhangi bir öngörüde bulunmaktan bilinçli olarak ve mutlak surette kaçınmaktadır. Makale, tarih disiplini ve siyaset bilimi-uluslararası ilişkiler disiplinleri arasındaki yaklaşım ve yöntem farklılıklarının Renouvin ve ondan etkilenen araştırmacıların geliştirdiği paradigmalara nasıl yansıdığı sorusuna yanıt aramayı amaçlamaktadır.

Anahtar Kelimeler: Diplomasi Tarihi, Siyasal Tarih, Tarih Yazımı, Pierre Renouvin, Uluslararası İlişkiler Kuramı.

\section{Beyond Diplomatic History: French School in the Historiography of International Relations}

\begin{abstract}
French historian Pierre Renouvin, in the works he published after the First World War, opened new paths in the historiography of international relations. In his studies of diplomatic events, Renouvin takes into account a manifold of factors, including social, economic, and cultural factors. Other historians, such as Jean-Baptiste Duroselle and René Girault, developed a similar perspective under the influence of Renouvin. The "French School of International Relations" attempted at developing a non-State-centric approach to the international relations, however, the state level has still a predominant role in their analyses. Regarding their methodology, they adopt an approach that departs from the particular level, and reaches the partial and general levels of explanation. The French School consciously avoids any future projection. The present article aims to seek to what extent the paradigms developed by Renouvin's and his followers' reflect the the methodological differences between the disciplines of history and political science-international relations.
\end{abstract}

Keywords: Diplomatic History, Political History, Historiography, Pierre Renouvin, International Relations Theory.

* Yrd. Doç. Dr., Siyaset Bilimi ve Uluslararası İlişkiler Bölümü, Siyasal Bilgiler Fakültesi, İstanbul Üniversitesi, İstanbul. E-posta: ates.uslu@istanbul.edu.tr. Bu yazı İstanbul Üniversitesi Bilimsel Araştırma Projeleri Komisyonu'nca 43727 numaralı proje çerçevesinde desteklenmiştir.

ULUSLARARASliLiŞKiLER, Cilt 11, Sayı 44, Kış 2015, s. 25 - 49 


\section{Giriş}

Disiplinlere ve bilim dallarının isimlerine verilen anlamlar, her ülkenin, her akademik geleneğin özgül bağlamına göre değişiklik gösterebilir. "Siyasal tarih" bu çerçevede en çarpıcı örnekler arasında yer almaktadır. Türkiye'de siyasal tarih çoğunlukla uluslararası ilişkiler ile tarihin kesişim alanında yer alan bir alt-disiplin olarak görülür; üniversitelerin akademik birimlerinin hiyerarşik diziliminde siyasal tarih anabilim dalı siyaset bilimi ve uluslararası ilişkiler bölümüne bağlı bir birim olarak yer alır. Batı academia'sında ise disiplinler arası hiyerarşilerin daha farklı bir şekilde kurulduğu gözlemlenmektedir. Türkiye'nin aksine birçok ülkede "siyasal tarih" tarihten ayrı (ya da görece özerk) bir disiplin olarak tarif edilmez, tarihte siyasal olguların analizine ağıllık veren bir yaklaşım olarak anlaşılır. Üstelik sadece siyasal olayların ve devletler arası ilişkilerin incelemesini yapmakla yetinen bu yaklaşım modern tarih yazımında yaygın bir şekilde eleştirilir. Yakınçăg'da (1789'dan sonra) uluslararası düzlemde gerçekleşen olayların incelenmesi için Anglosakson literatüründe uluslararası tarih (international history), Fransız literatüründe uluslararası ilişkiler tarihi (bistoire des relations internationales) gibi alternatif adlandırmalar 20. yüzyllın ikinci yarısında yaygınlaşmı̧ ve "siyasal tarih" ya da "diplomasi tarihi" gibi terimler giderek daha az kullanılmaya başlanmıştır. Bilim dalı adlarında görülen bu değişiklik, yöntemsel yaklaşımlarda gerçekleşen bir dönüşümü de yansıtır, keza artık salt siyasal olayların, savaşların ya da diplomatik hamlelerin tarihinin anlatımı ve incelenmesiyle yetinilmemekte, uluslararası ilişkiler, toplumsal tarih, iktisat tarihi, kültür tarihi gibi çeşitli alanların verilerinden de yararlanılarak tarihsel bir çerçeveye yerleştirilmektedir.

Bu çalışmada, Birinci Dünya Savaşı'nın ertesinde oluşmaya başlayan, İkinci Dünya Savaşı sonrasında ise olgunluk dönemine ulaşan bir tarih yazımı ekolünün genel özellikleri tahlil edilecektir. "Uluslararası ilişkiler tarihinde Fransız Okulu", ${ }^{1}$ hatta "Uluslararası İlişkilerde Fransız Okulu” olarak adlandırılan bu akım, özellikle 20. yüzyılın ikinci yarısında Anglosakson uluslararası ilişkiler literatürünün tüm akademik dünyada yaygınlık kazanmasına paralel olarak dünya çapında bir tanınırlı̆ga ulaşmamışır. Bu nedenle gerek uluslararası ilişkiler kuramları ve yaklaşımları, gerekse tarih yazımı yaklaşımları söz konusu olduğunda Fransız tarihçi Pierre Renouvin’in (1893-1974) kurduğu bu ekol göz ardı edilebilmektedir. Oysa tarihçi René Girault'ya göre bu ekol yakınçağ tarihinin yazımının gelişiminde Annales ekolünün oynadığı rolle kıyaslanabilecek bir rol oynamıştır. ${ }^{3}$ Renouvin'in Paris Üniversitesi'nde verdiği dersler ve yönettiği tezler özellikle İkinci Dünya Savaşı'nı izleyen yıllarda uluslararası ilişkiler tarihi alanında çalışan bir araştırmac1-akademisyen grubunun ortaya çıkmasına çerçeve oluşturmuştur. Gerek Renouvin'in, gerekse çalışma arkadaşlarının yaptıkları yayınlar da bir yandan uluslararası ilişkiler tarihi

1 André Martel, “De la 'question d'Orient' aux affaires des Balkans ou du recours à l'histoire et de ses limites”, Jean-Robert Henry ve Gérard Groc (der.), Politiques méditerranéennes entre logiques étatiques et espace civil: Une réflexion franco-allemande, Paris, Karthala-IREMAM, s. 58.

2 Jean-Paul Depretto, "René Girault (1929-1999)”, Revue des études slaves, Cilt 71, No 3-4, 1999, s.744; Stanislas Jeannesson, "Diplomatie et politique étrangère de la France contemporaine: Un bilan historiographique depuis 1990”, Histoire, économie E̋ société, Cilt 31, No 2012/2, s. 97.

3 René Girault, "Pierre Renouvin, la BDIC et l'historiographie française des relations internationales", Matériaux pour l'bistoire de notre temps, No 49-50,1998, s. 7. 
literatürünün gelişmesini sağlamış, diğer yandan da söz konusu grubun araştırma yöntemleri ve tarih yazımı konusundaki konumlanışlarını belirginleştirmiştir. Renouvin ekolünün önemi, esas olarak, bu ekolün temsilcilerinin siyasal olaylar ile bu olayların parçası olduğu toplumsal-iktisadi-kültürel formasyon arasındaki dolayımları, değişken bağlantıları incelemeye verdikleri önemden ileri gelmektedir. Başka bir deyişle, söz konusu ekol siyasal olayların kronolojik sıralamasıyla yetinmemekte, bu olayları bütünsel bir bağlamın parçaları olarak, ele almakta, "olay”lar ve "olgu”lar arasındaki ilişkiyi ortaya çıkarmaktadırlar. Bu yönteme göre kuram, ancak olaylardan yola çıkarak uluslararası olguların incelenmesinin sonucunda ulaşılan bir genellemedir.

Renouvin'in ve izleyicilerinin uluslararası ilişkiler tarihinin yeniden yorumlanmasına katkılarının serimleneceği bu çalışmada, ilk olarak Renouvin’in geliştirdiği uluslararası ilişkiler tarihi yaklaşımına ve tarih yazımına yaptığı başlıca katkı olan "dipteki kuvvetler" kavramına değinilecektir. İkinci bölüm, Renouvin’in uluslararası ilişkiler tarihi metodolojisine katkı niteliğinde olan geç dönem eserlerinin incelenmesine ayrılmıştır. Son bölümde ise Renouvin'in etkisinde eser veren tarihçilerin ve uluslararası ilişkiler uzmanlarının “usta”larının 1974 yılındaki ölümünden sonra yaptıkları başlıca araştırma ve sentez faaliyetlerine ve ortaya koydukları kurumsallaşma çabalarına değinilecektir. Çalışmanın bütününde, tarih disiplini ve siyaset bilimi-uluslararası ilişkiler disiplinleri arasındaki yaklaşım ve yöntem farklılıklarının Renouvin ve ondan etkilenen araştırmacıların geliştirdiği paradigmalara nasıl yansıdığı sorusuna yanıt aranacaktır. Daha genel bir düzlemde ise, olaylar-olgular ve kuram arasındaki ilişkinin Renouvin ekolünün metodolojisinde nasıl şekillendiği incelenecektir. Robert Frank ve Jacques Thobie gibi halen aktif olan Renouvin ekolü üyelerinin çalışmaları ise bu makalenin inceleme kapsamı dişında tutulmuştur.

\section{Büyük Savaş'ın Tarihinin Yazımından Uluslararası İlişkiler Tarih Yazımının Yenilenmesine}

\section{“Büyük Savaş”ve Renouvin’in Yöntemsel Açılımları}

Fransa'da 19. yüzyıl sonu ve 20. yüzyıl başında tarih ve siyaset bilimi-uluslararası ilişkiler disiplinlerinde önemli aşamalar kaydedilmişti. 19. yüzyılın sonlarında Charles Seignobos ve Charles-Victor Langlois'nın öncülük ettiği pozitivist tarih yaklaşımı yaygınlaşmıştı. $\mathrm{Bu}$ yaklaşımda tarih; tarihsel belgelerin (çok büyük çoğunlukla resmi belgelerin) kritik incelenmesinden yola çıkılarak geçmişteki siyasal olayların tasvir edilmesine dayalı bir bilimsel disiplin olarak görülüyordu. Tarih eğitiminin başlıca merkezi Paris Üniversitesi Edebiyat Fakültesi idi. Siyaset bilimi alanında 1872'de kurulan Siyasal Bilimler Özgür Okulu (École libre des Sciences politiques) önemli bir rol oynuyordu; söz konusu enstitünün bünyesinde yakınçağ tarihi alanında faaliyet gösteren profesörlerin kurduğu kürsüler yer alıyordu. Aynı dönemde uluslararası ilişkiler eğitimi hukuk fakültelerinde yapılıyordu ve devletler arası ilişkilerle sınırlanıyordu. ${ }^{4}$ Uluslararası ilişkiler tarihinin yazımı da Al-

4 René Girault, Diplomatie européenne: Nations et impérialisme, 1871-1914, Paris, Armand Colin, [1979] 1997, s.1. 
bert Sorel, Albert Vandal ve Émile Bourgeois gibi tarihçilerin etkisiyle siyasal kararların, diplomatik müzakerelerin ve savaşların resmi belgelerden yola çıkılarak tasvir edilmesi yöntemiyle yapıliyordu.

Pierre Renouvin, Paris Üniversitesi’nde hukuk diplomasını aldıktan sonra tarihe yöneldi. Birinci Dünya Savaşı (dönemin yaygın adlandırmasıyla "Büyük Savaş") sırasında cepheye gönderildi; Nisan 1917'de aldığı ağır yara bir kolunu kaybetmesine neden oldu. Savaşın hemen ertesinde Alphonse Aulard'ın danışmanlığında bir tez hazırladı. ${ }^{5}$ Aulard bu dönemde Fransız Devrimi tarihçiliğinin en önemli ismiydi; Renouvin'in hazırladığg tez de 1787'de Fransa'daki il meclislerini konu alıyordu. Bununla birlikte, savaş sonrasında André Honnorat'nın eğitim bakanlığı döneminde kurulan Savaş Tarihi Kütüphanesi’nin başına getirilmesi araştırmalarında yoğunlaştığı konuların değişmesine neden oldu: Renouvin 1920'lerin başından itibaren Büyük Savaş'ın ve bu savaşı önceleyen yılların tarihinin uzmanı olarak tanındı. Yine bu dönemde yayınlanmaya başlayan Fransız Diplomatik Belgeleri kitap dizisinin editörlük faaliyetlerinde önemli bir rol oynadı.

Gerek Savaş Tarihi Kütüphanesi projesi, gerekse Fransız Diplomatik Belgeleri dizisi bu dönemde Fransız hükümetlerinin savaşı Fransa perspektifinden değerlendirme (dolayısıla kazananların gözünden tarih yazma) hedefine hizmet ediyordu. Bununla birlikte, Renouvin'in rolü bir resmi tarihçi rolünden çok öteye geçti. Yazar esas olarak belge merkezli klasik diplomasi tarih yaklaşımı geleneğine bağlı kalıyordu. Ancak savaşın ertesinde gelişen yeni tarih yaklaşımlarına da kayıtsız kalmamıştı. Büyük Savaş sonrası dönemde Henri Berr, Marc Bloch, Lucien Febvre ve Georges Lefebvre gibi tarihçiler Fransız tarihsel araştırmalarına yeni açılımlar getirmekteydiler. ${ }^{6} \mathrm{Bu}$ şekilde pozitivist yaklaşımın tarihçiler arasındaki hegemonyası sarsılmış, belgeci tarihçiliğin işaret ettiği siyasal olayların temelindeki yapısal hareketleri kavramaya çabalayan bir tarih yazımı yaklaşımı gelişmiş̧ti. Yeni yaklaşımlarda tarih kendi içine kapalı bir alan olarak değil; coğrafya, sosyoloji, iktisat, psikoloji gibi çeşitli disiplinlerle diyalog içinde bir disiplin olarak ortaya çıkıyordu. ${ }^{7}$ Marc Bloch ve Lucien Febvre'in inisiyatifiyle 1929'da yayına başlayan Annales dergisi bu yeni yaklaşımların başlıca gelişme mecrası haline geldi.

Pozitivizmi reddeden yaklaşımların yaygınlaşmaya başladığı bu dönemin başlarında, 1921 yılında Renouvin’in yayınladığı bir makale genç tarihçinin gerek tarihsel yönteme yaklaşımı konusunda ipuçları vermesi, gerekse tarihsel yöntem ve uluslararası ilişkilere yaklaşımı arasında kurduğu bağlantıyı göstermesi açısından ilgi çekici niteliktedir. Renouvin, bu makalesinde, günlük basının incelenmesinin tarihçilerin çalışması için büyük önem arz ettiğini belirtir. ${ }^{8}$ Resmi belgelerin yansıtmasının mümkün olmadığ 1 toplumsal dönüşümler ya da iktisadi sorunlar günlük gazetelerde yayınlanan haberler üzerinden izle-

5 Jean-Baptiste Duroselle, "Pierre Renouvin (1893-1974)", Revue d'Histoire moderne et contemporaine, Cilt 22, 1975, s.498.

6 Pierre Renouvin, "Research in Modern and Contemporary History: Present Trends in France", The Journal of Modern History, Cilt 38, No.1, 1966, s.1.

7 Guy Bourdé ve Hervé Martin, Les écoles historiques, Paris, Seuil, 1990, s.216-217.

8 Pierre Renouvin, "La Presse et l'histoire", Matériaux pour l'histoire de notre temps, No.49-50, 1998, s.83. [İlk basim: Revue de Synthèse historique, Cilt 33, No.97-99, 1921]. 
nebilir. Renouvin özellikle Büyük Savaş yıllarında gazetelerin büyük ölçüde sansürlenmiş olmasının da etkisiyle, basının bütünüyle özgür olmadığının altını çizer. Buna karşılık, sansürün varlığına rağmen gazetelerin "kamusal ruh" u yansitabileceğini öne sürer. " "Kamusal ruh" olarak adlandırdığı olguya daha sonraki yazılarında "kolektif psikoloji” adını verir ve uluslararası ilişkilerin temel güçlerinden biri olarak kabul eder. Renouvin'in "kamusal ruh"u inceleme konularından biri olarak görmesi, diplomasi tarihi ve askeri tarih ağırlıklı çalışmalarına paralel olarak yeni bir yaklaşım geliştirmeye başladığını gösterir.

Renouvin, aynı makalesinde, basın ve kamusal ruh üzerine genel tespitlerden sonra gazetelerin incelemesinin yapılması için yöntem önerileri getirir. Bir uluslararası olayın basın üzerinden gerçek anlamda araştırılabilmesi için tüm ilgili ülkelerdeki yayın organlarının incelemeye tâbi tutulması gerekir. Ancak bu altından kalkılması çok zor bir iştir. Renouvin bu noktada basın bültenlerinden yararlanılmasını önerir; çeşitli ülkelerde ve çeşitli kurumlarca yayınlanan ve çeşitli gazete haberlerinin özetini içeren bu bültenler gazete taramasının yerini tutmasa da gazete taramaları için bir rehber niteliği taşıyabilir. ${ }^{10}$ Yazar makalede Fransa başta olmak üzere pek çok ülkede yayımlanan basın bültenleri hakkında ayrıntılı açıklamalar verir. Kaynakların çeşitliliğine yaptığı vurgu, uluslararası ilişkiler tarihi yaklaşımının Fransa merkezli olmaktan uzak olduğunu gösterir; bu şekilde tarihsel olay ve olgular hakkındaki kaynakların çeşitliliğine vurgu yapar ve her olayın farklı ülkelerin arşiv belgelerinde farklı yansımalarının olduğunu ima eder. Büyük Savaş'ın ertesinde Fransa'da ulusçu-yurtsever söylemlerin yaygınlığı ve Renouvin'in ulusal bir tarih yorumu yapmakla görevlendirildiği göz önünde bulundurulursa, bu yaklaşımın dönemin koşulları içindeki yenilikçi niteliği anlaşılabilir.

Renouvin'in iki savaş arası dönemde uluslararası ilişkiler tarih yazımına getirdiği açılımlardan bir diğeri, sözlü tarih yöntemlerinin kullanımıdır. Bu noktada örnek olarak 1936 yılında Fransız diplomat Maurice Paléologue ile gerçekleştirdiği görüşmeden yola çıkarak yaptığı sözlü tarih çalışması incelenebilir. Renouvin, esas olarak Paléologue'un Büyük Savaş'ın çıktığı sırada yürütmekte olduğu Saint-Petersburg büyükelçiliği görevi sırasındaki faaliyetleriyle ilgili olarak yaptığı bu çalışmada klasik diplomasi tarihi yaklaşımlarını anımsatan bir yaklaşım benimsemekte, diplomatik hamleleri tüm ayrıntılarıyla incelemeye çabalamaktadır. ${ }^{11}$ Sözlü tarih yaklaşımıyla, belgelere geçmeyen, hatta bazen önemli devlet görevlilerinin bile emin olmadığı konularda tahmin yürütülmesi kolaylaşır. Renouvin’in, sözlü tarih çalışması Paléologue'un görüşme sırasındaki tutum ve tavrına, endişelerine ve rahatsızlıklarına da özel bir önem atfettiği ve verdiği bilgileri yorumlarken bu unsurları göz önünde bulundurduğu görülür, ${ }^{12}$ bu şekilde, resmi kaynaklara eleştirel yaklaşım ilkesini sözlü tarih kaynaklarına da uygular. Bununla birlikte, Renouvin resmi belgelerin önemini yadsıma yoluna da kesinlikle girmez, hatta 1920'lerin ortasından itibaren yakın tarih üzerine doktora tezi yazmak isteyen öğrencilerinin tez konusu önerilerini, bu döneme ilişkin arşiv belgele-

9 Ibid.

10 Ibid., s.84-85.

11 Pierre Renouvin, "Entretien avec Maurice Paléologue, le 12 février 1936", Matériaux pour l'histoire de notre temps, No.47, 1997, s.61.

12 Ibid., s.63. 
rinin araştırmacılara açık olmadığı gerekçesiyle reddeder. Dolayısıyla Renouvin’e göre tarih araştırmasının belkemiğini halen resmi belgeler oluşturmaktadır.

Renouvin'in geleneksel belge kritiği yöntemleriyle yenilikçi yöntemleri sentezleyerek sürdürdüğü ilk dönem araştırmaları, 1925 yılında ilk büyük sentez çalışmasının yayımlanmasıyla sonuçlandı. Bu tarihte yayımladığı kitabın başlığı Les Origines immédiates de la guerre (Savaş’n Yakın Nedenleri) idi. Renouvin 1922-1923'te Paris Üniversitesi’nde verdiği derslerden hareketle hazırladığı bu kitabında 1914'te savaşın başlamasını önceleyen yaklaşık bir aylık dönemi ayrıntılarıyla inceliyordu. Kitap esas olarak diplomasi tarihinin geleneksel belge-merkezli yöntemi kullanılarak yazılmıştı. Ancak kitabın içeriği son derece yenilikçiydi, keza Renouvin Fransada yerleşik olan resmi yorum savaşın çıkmasının tek sorumlusu olarak Almanya ve Avusturya-Macaristan'ın politikalarını gösterirken, Renouvin savaş ilanına yol açan diplomatik örgüyü tüm karmaşıklığı içinde ve tarafsızlık kaygısı güderek inceliyordu. Dolayısıyla yazarın yaklaşımına göre savaşın çıkmasından bir ya da birkaç ülkenin sorumlu tutulması mümkün değildi; bir dizi yapısal ve siyasal sorun savaşın ortaya çıkmasına neden olmuştu.

Fransa'da uluslararası ilişkiler tarihini diplomasi tarihi ile sınırlı tutan yaklaşımların eleştirisi 1930'lu y1llarda gerek Annales ekolünün, gerekse Marksist (ya da Marksizm'den etkilenen) tarihyazımının etkisiyle başlamıştı. ${ }^{13}$ Renouvin, Annales çevresi, Marksist tarihçiler ve Ernest Labrousse gibi iktisat tarihçilerinin oluşturduğu, siyasal olayların incelenmesinin ötesinde orta ve uzun vadeli iktisadi-toplumsal dönüşümlerin incelenmesine vurgu yapan blok ile pozitivist tarihçiler arasında 1930'lu yıllarda yapılan tartışmalarda belirgin bir tavır almadı, hatta bazı noktalarda pozitivistlere yakın bir tavır benimsedi. Renouvin'in 1934 tarihli çalışması La crise européenne et la Grande guerre (Avrupa Krizi ve Büyük Savaş), Louis Halphen ve Philippe Sagnac adlı pozitivist tarihçilerin girişimiyle Birinci Dünya Savaşı sonrasında yayına başlayan Peuples et Civilisations (Halklar ve Uygarlıklar) kitap dizisinin 19. cildi olarak yayımlandı. Renouvin’in eserinin ağırlık noktasını Birinci Dünya Savaşı'nın askeri ve siyasal tarihinin anlatıldığı bölümler oluştursa da, yazar ilk sayfalardan itibaren savaşın incelenmesinin savaşın kökenlerinin incelenmesinden ayrılamayacağını belirtiyordu. Dolayısıyla Birinci Dünya Savaşı'nın tarihini yazmak için savaşın 19. yüzyıl sonlarında şekillenen "derin sebeplerine" değinmek, iktisadi emperyalizmin, kolonyal yayılmanın ve "ulusal kibir"in tahlilini yapmak kaçınılmazdı; buna bağlı olarak, kitabın ilk bölümlerinde 1904 ve 1918 arasındaki dönemde tüm dünyanın tarihini inceliyordu. ${ }^{14}$ Kitabın son kısmı ise savaşın siyasal, iktisadi, toplumsal, dini ve kültürel hayatta meydana getirdiği dönüşümlerin incelenmesine ayrılmıştı. ${ }^{15}$ Görüldüğü gibi, yazar gerek resmi belgelere, gerekse siyasal olayların aktarımına verdiği önemle pozitivistlere yakın bir konumda yer alıyor, bununla birlikte araştırma kaynaklarını resmi belgelerin d1şındaki kaynaklarla çeşitlendiriyor, iktisadi verileri ve kamuoyuna ilişkin kaynakları (örneğin demografik verileri, fiyat dalgalanmalarına ilişkin istatistikleri ve sanat tarihine ilişkin bilgileri) dikkate alarak araştırma alanını genişletiyordu.

13 René Girault, "Le difficile mariage de deux histoires: Économie et relations internationales dans le monde contemporain", Être historien des relations internationales içinde, Paris, Publications de la Sorbonne, [1985] 1998, s.39.

14 Pierre Renouvin, La crise européenne et la Première Guerre mondiale, Paris, PUF, 1962, s.1-2.

15 Ibid., s.647-739. 


\section{Diplomasi Taribinin Reddinden Uluslararası İlişkiler Taribi Üzerine Sentez Denemelerine}

Renouvin 1930'ların ortasından 1960'lara uzanan dönemde uluslararası ilişkiler yaklaşımının temellerini oluşturdu; bu yeni yaklaşım özellikle İkinci Dünya Savaşı'ndan sonra olgunluğa ulaştı. ${ }^{16}$ Buna göre devletler arası ilişkilerin incelenmesinde devlet adamlarının, dışişlerinden sorumlu kurum ve kişilerin rolünün dikkate alınması yetersiz bir yaklaşımdı. Araştırmalarını bu alanlarla sınırlı tutan geleneksel "diplomasi tarihi” yaklaşımlarına karşı devlet adamları ve "dipteki kuvvetler" arasındaki ilişkiyi dikkate alan yeni bir tarih yaklaşımı geliştirmek gerekiyordu. Bu noktada Renouvin'in "dipteki kuvvetler" tanımını yaparken iki kaynaktan etkilendiğini belirtmek gerekiyor. ${ }^{17}$ Renouvin, Annales ekolünün bu dönemdeki en önemli temsilcisi olan Fernand Braudel'den, özellikle de Braudel'in İkinci Dünya Savaşı'nın sonrasında yayımlanmış olan La Méditerranée et le monde méditerranéen à l'époque de Philippe II (II. Felipe Döneminde Akdeniz ve Akdeniz Dünyası) kitabından hareketle maddi yaşam koşullarının ve iktisadi yapıların önemine dikkat çekiyordu. Bunun yanında, İtalyan tarihçi Frederico Chabod'dan (özellikle 1951 tarihli Storia della politica estera italiana dal 1870 al 1896 - 1870'ten 1896'ya İtalyan Dı̧̧ Politikasının Taribi) ${ }^{18}$ kitabından etkilenerek kamuoyu, ulusal kimlik gibi kavramları tarih yazımında dikkate alıyordu. Renouvin'in bu dönemde yaygin olarak kullanmaya başladığı ifadelerle, maddi ve manevi "dipteki kuvvetler", uluslararası ilişkilerin temelini teşkil ediyordu; dolayısıyla uluslararası ilişkilerin tarihi artık diplomasi tarihi olmaktan çıkmal, siyasal kararları etkileyen iktisadi ve toplumsal güçleri de kapsayacak şekilde genişletilmeliydi.

Renouvin, 1953-1958 arasinda yayımlanan Histoire des Relations internationales (Uluslararası İlişkiler Taribi) ${ }^{19}$ dizisinde bu yeni yaklaşımı ve yöntemi uyguladı. Kitap sekiz ciltten oluşuyordu. Ortaçağ hakkındaki ilk cilt Belçikalı tarihçi François-L. Ganshof tarafindan, Yeniçăg hakkındaki iki cilt Alsace kökenli tarihçi Gaston Zeller tarafından kaleme alınmıştı. Fransız Devrimi ve Napoléon İmparatorluğu döneminde uluslararası ilişkiler tarihini ele alan dördüncü cildin yazarı ise André Fugier idi. Renouvin, 1815-1945 dönemini ayrıntılarıyla inceleyen son dört cildin yazımını üstlenmişti. Ganshof, Zeller ve Fugier, kendi ciltlerini yazarken Renouvin'in kaleminden çıkmış olan "Genel Giriş” te sunulan esaslara riayet etmeye çalışıı̧lardı. Renouvin bu giriş kısmında "diplomatik" tarihin devlet adamlarının hamleleriyle sınırlı olan dar bakış açısının aşılması gerektiğini belirttikten sonra önemli olanın "balklar arasındaki ilişkilerin tarihi" olduğunun altını çiziyordu. ${ }^{20}$ Yazar, Braudel'in temsil ettiği yapısal tarih yaklaşımının maddi şartları ve iktisadi dönüşümleri temel ala-

16 Girault, "Pierre Renouvin, la BDIC et l'historiographie française des relations internationales", s. 504.

17 Pierre Renouvin, "Introduction générale”, Renouvin, Pierre (der.), Histoire des Relations internationales: I: Du Moyen Âge à 1789, Paris, Hachette, [1953] 1994, s. 8; ayrıca bkz. Jean-Baptiste Duroselle, L'Europe de 1815 à nos jours, Paris, PUF, 2002, s. 268.

18 Federico Chabod, Storia della politica estera italiana dal 1870 al 1896, Bari, Laterza, [1951] 1997.

19 Renouvin, Pierre (der.), Histoire des Relations internationales: I: Du Moyen Âge à 1789, Paris, Hachette, [1953] 1994.

20 Renouvin, "Introduction générale", s.8. 
rak tarih incelemeleri yaptığını hatıllatıyordu. Chabod'nun temsil ettiği yaklaşım ise tarih incelemelerinde insanların ruh halini, ulusal bilincin gelişimini dikkate alıyordu. Her iki yaklaşım gerçekliğin farklı boyutlarını temsil eder, dolayısıyla olguların bütünlüklü bir tahlili için gerek öznel, gerekse yapısal faktörlerin dikkate alınması gerekir. Renouvin bu görüşten hareketle kitapta dört yazar tarafindan benimsenen yöntemi özetler: Renouvin, Ganshof, Zeller ve Fugier devletler arası ve halklar arası ilişkilerdeki önemli dönüşümleri ve bunların nedenlerini incelerken gerek -siyasal nitelikte- çatışmaları, gerekse maddi ya da manevi nitelikli "dipteki kuvvetler"i dikkate alacaklardır. Bu şekilde uluslararası ilişkiler tarihi, tarihin diğer araştırma alanlarından uzak bir alan olmaktan çıkar ve genel tarihin bir parçası haline gelir. ${ }^{21}$ Uluslararası İlişkiler Taribinde yer alan bu vurgu, Renouvin'in daha sonraki çalışmalarında da karşımıza çıkar. Renouvin, öğrencisi Jean-Marie Mayeur'ün deyişiyle her zaman genel tarihi göz önünde bulundurmuş, birbirinden bütünüyle ayrık, kendi içine kapalı alt uzmanlık alanlarıyla sınırlı kalmak istememiştir. Örneğin din tarihi, toplumsal tarih ve siyasal tarih arasında mutlak bir ayrımdan yola çıkarak çalışma yapmak mümkün değildir. ${ }^{22}$

Renouvin’in geliştirdiği yaklaşım kitabın yazarları üzerine olduğu kadar dönemin diğer tarihçileri üzerine de etkili olmaya başlamıştı. Sorbonne'da 1945-1949 arasında Renouvin'in asistanlığını yapmış olan Jean-Baptiste Duroselle'in çalışmaları bu noktada örnek olarak verilebilir. Fransız Siyasal Bilimler Derneği’nin Haziran 1953'te düzenlediği "Dış politika ve temelleri” başlıklı tartışmada Duroselle Renouvin'in yaklaşımlarını anımsatan bazı tezler öne sürüyordu. Duroselle'e göre iktisadi çevrelerin dış politikadaki etkileri gibi konularda gazetecilik tarzının ve temelsiz suçlamaların ötesine geçerek genel bir uluslararası ilişkiler kuramına ulaşmak mümkündür; bu kurama sosyoloji ve tarih yöntemleri kullanılarak ulaşılabilirdi. ${ }^{23}$

Renouvin'e kıyasla Duroselle devlet merkezli tarih anlayışına daha yakındı; eserlerinde olayların aktarımı ve ampirizm Renouvin'in eserleriyle karşılaştırılırsa daha ön plana çıkıyordu. ${ }^{24}$ Duroselle Annales ekolüne karşı mesafeliydi ve bu ekolün mensuplarını model geliştirmeye özel bir önem atfedip bu modelleri inceledikleri alana uygulamakta yetersiz kalmakla suçluyordu. ${ }^{25}$ Duroselle, güncel fenomenlerin incelenmesinin zorluklarına dikkat çeker ve açıklayıcı hipotezler ve kanıtlanmı̧ olgular arasında ayrım yapılması gerektiğini savunur. Ona göre kanıtlanmış olgular şimdiki zamana yaklaştıkça daha zor ulaşı1ır nitelik kazanmaktadır. Bu nedenle araştırmacıların tarih araştırmaları yapmaları ve tarihsel olay ve olguların evriminin genel yönelimi hakkında tahlil yapmaları gerekmektedir. ${ }^{26}$ Duroselle'in 1953 tarihinde (Renouvin'in editörlüğünde hazırlanan Uluslararast

21 Ibid., s.11.

22 Jean-Marie Mayeur, "Pierre Renouvin et l'histoire religieuse", Revue d'bistoire de l'Église de France, Cilt 63. No.170, 1977, s.103, 105.

23 Stanley Hoffmann, "Compte rendu de la table ronde sur les fondements de la politique étrangère, 13-14 juin 1953”, Duroselle, Jean-Baptiste (der.), La politique étrangère et ses fondements, Paris, Armand Colin, s.376.

24 Jean-Jacques Roche, "L'enseignement des relations internationales en France: Les aléas d'une 'discipline-carrefour", Revue internationale et stratégique, No.47, 2002, s.103.

25 Ibid., s.102.

26 Hoffmann, "Compte rendu de la table ronde sur les fondements de la politique étrangère", 
İlişkiler Taribi’nin ilk cildiyle aynı tarihte) yayımladığ1 1919'dan Günümüze Diplomasi Taribi ${ }^{27}$ başlıklı kitabının klasik devletler arası ilişkiler tarihi yaklaşımına yakın bir yöntemle yazılmış olması dikkate değerdir.

Bir bütün olarak incelendiğinde Renouvin'in ve çevresindeki tarihçilerin uluslararası ilişkiler tarihine yaklaşımının Birinci Dünya Savaşı sonrasında siyasal olaylarla sınırlı kalmayarak ekonomik ve toplumsal yapı ile dinamikleri tarih incelemelerine dâhil eden tarih yazımı açılımları içinde değerlendirilmesi gerektiği belirtilmelidir. Uluslararası ilişkileri toplumsal ve ekonomik formasyonun bütünü içinde değerlendirmeye çabalayan Renouvin ve çalışma arkadaşları, özellikle 1950'li yıllarda bu düzlemde önemli aç1lımlar getirmişlerdir. Buna karşılık, Duroselle gibi yazarların bu dönemlerde yayınladıkları eserlerden de anlaşılabileceği gibi, uluslararası ilişkiler tarihini diplomasi tarihi olarak yorumlama yönündeki tarih yazımı geleneği dönemin tarihçileri arasında baskınlığını korumuştur.

\section{Tarih İncelemelerinden Uluslararası İlişkiler Kuramına Geçiş}

\section{Tarih Yazımı ve Siyaset Bilimi Geriliminde Renouvin’in Geç Dönem Çalışmaları}

Pierre Renouvin 1959-1971 arasında Ulusal Siyaset Bilimi Vakfi ${ }^{28}$ başkanlığı görevini üstlendi; Duroselle'e göre Renouvin bu görevi üstlendikten sonra tarih ile siyaset bilimi gibi disiplinler arasında bağlantılar kurulabileceği yönünde görüşlere daha açık hale geldi. ${ }^{29}$ Renouvin bu dönemdeki çalışmalarında tarih ve siyaset bilimi arasında yöntemsel bir ayrımı öne çıkarmaya başladı. Tarihçiyi bir dizi tekil olayı ve bunların arasındaki özgül bağlantıları inceleyen bir uzman olarak görüyordu. Siyaset bilimci ise karşılaştırmalar yapan, genel açıklamalar öneren ve genel kanunları bulmaya çalı̧̧an bir uzman olarak tanımlanabilirdi. ${ }^{30}$ Renouvin, somut fenomenleri derinlemesine incelemeden bu fenomenler hakkında soyutlamalara başvurarak spekülasyon yapma eğilimlerini eleştiriyordu; ona göre tarihin dışında, ya da tarihin siyaset bilimciye sunduğu verilerin dışında bir siyaset bilimi olamazdi. ${ }^{31}$

Renouvin'in fenomenlerin derinlemesine incelenmesi için önerdiği yöntemler her şeyden önce klasik tarih yazımı yöntemleridir. Tarih araştırmasının gereğince yapılabilmesi için araştırılan konuyla ilgili belgeler içeren kamu arşivlerinin ve özel arşivlerin müm-

s.378.

27 Jean-Baptiste Duroselle, Histoire diplomatique de 1919 à nos jours, Paris, Dalloz, [1953] 1993.

28 Siyasal Bilimler Özgür Okulu (École libre des Sciences politiques), 1945 y1lında Paris Siyasal Bilimler Enstitüsü (Institut d'études politiques de Paris) adını almıştı. Aynı yıl kurulan Ulusal Siyaset Bilimi Vakfi, enstitünün idaresini sağlıyordu.

29 Jean-Baptiste Duroselle, "Pierre Renouvin et la science politique", Revue française de science politique, Cilt 25, No 3, 1975, s.561.

30 Ibid., s.564.

31 Ibid., s.573-574. 
kün olduğunca ulaşılır olması gerekmektedir. ${ }^{32}$ Devlet arşivlerinin belirli bir tarihe kadar araştırmacılara kapalı tutulması kuralı, Birinci Dünya Savaşı sonrası dönem gibi yakın tarih konularının yeterince ilgi görmemesi sonucunu doğurmaktadır. ${ }^{33}$ Belgelerin yanında, tıpkı 1920’lerde olduğu gibi bu dönemde de sözlü tarih çalısmalarının önemine dikkat çeker, öğrencilerini yaşayan kişilerin tanıklıklarını toplamaya teşvik eder. ${ }^{34}$ Dönemin tarih araştırmalarındaki başlıca eksikliklerden birinin yabancı ülkelerin tarihine yeterli derecede ilgi duyulmaması olduğunu belirtir; gerek konuların işlenişinde zenginliğe ulaşılması için, gerekse belge çeşitliliğinin sağlanması için bu ilginin artırılması gerekmektedir.

Renouvin, 1950'lerin sonunda Fransız tarihçilerin uygarlık tarihine yönelik ilgisinin arttığını gözlemler ve Fernand Braudel’in 1958 tarihli bir metninde yer alan, uygarlık tarihi incelemelerinin gelişmesinin gerektiğine ilişkin sözlerini aktarır. Braudel'in aşamalı gelişmelerin, uzun dönemli dalgalanmaların, demografik eğilimlerin, maddi yaşam koşullarının ve ulaşım araçlarının, iktisadi etkinliklerin gelişiminin incelenmesinin önemine dair sözleri, Renouvin'in tarih incelemelerinde benimsediği yöntemi anımsatır niteliktedir. Kaldı ki Renouvin bu sözleri alıntıladıktan hemen sonra tarihçilerin iktisat, etnoloji, toplumsal psikoloji ve demografinin yöntemleri hakkında bilgi sahibi olması gerektiğini belirtir ve uluslararası düzlemde diplomatik tarihin geleneksel çerçevesinin aşılması gerektiğinin altını çizer. ${ }^{35}$ Özetlemek gerekirse, Renouvin bu dönemde Braudel'in bütünsel tarih yaklaşımını takip etmekte ve bu yaklaşımın uluslararası ilişkiler tarihinin yeniden yazımına ve yorumlanmasına da katkıda bulunacağını düşünmektedir.

\section{Uluslararası İlişkiler Taribinin Metodolojisi: "Uluslararası İlişkiler Taribine Giriş"}

Renouvin, uluslararası ilişkilerin dipteki kuvvetleri üzerine 1950'li yılların sonunda geliştirdiği görüşlerini kısa bir süre içinde bir sentez haline getirmeye başladı. Yazarın JeanBaptiste Duroselle ile kaleme aldığ Introduction à l'histoire des relations internationales (Uluslararası İlişkiler Tarihine Giriş) başlıklı kitabının ilk baskısı 1964 yılında yapıldı. ${ }^{36}$ Yazarlar kitabın giriş kısmında uluslararası ilişkileri devletlerin arasındaki ilişkiler olarak tanımlarlar. Devlet ise "bir toprak üzerinde örgütlenmiş olan siyasal topluluk"tur. ${ }^{37}$ Buna karşılık, bu tanımın hemen sonrasında, halkların ve bu halkları oluşturan bireylerin arasındaki ilişkilerin de uluslararası ilişkiler incelemelerinde dikkate alınması gerektiğini belirtirler. Bu vurguya rağmen yazarların uluslararası ilişkiler anlayışında devletin ve hükümetlerin belirleyici nitelikte olduğu görülür, keza devletler iktisadi ilişkiler, fikir alı̧verişleri gibi alanlara müdahale ederek bu alanlarda değişiklik yapma yetisine sa-

32 Ibid., s.561-562.

33 Renouvin, "Research in Modern and Contemporary History: Present Trends in France", s.2.

34 Mayeur, "Pierre Renouvin et l'histoire religieuse", s.105.

35 Renouvin, "Research in Modern and Contemporary History: Present Trends in France", s. 1.

36 Pierre Renouvin ve Jean-Baptiste Duroselle, Introduction à l'histoire des relations internationales, Paris, Armand Colin, [1964] 1970.

37 Ibid., s.1. 
hiptir. Devletin merkeziliği konusunda Raymond Aron'un Paix et guerre entre nations (Uluslar Arasında Barış ve Savaş) başlıklı kitabına atıf yapmaları ve bibliyografyada Hans Morgenthau'nun Politics among Nations (Uluslar Arası Politika) kitabına öncelikli bir yer ayırmaları, uluslararası ilişkilerde Gerçekçi yaklaşımları benimseyen yazarları yakından takip ettiklerini ve olumladıklarını gösterir. Ancak uluslararası ilişkilerde "devlet adamı" ve "dipteki kuvvetler" in karşılıklı etkileşim içine girdiklerini vurgulayarak klasik Gerçekçi yaklaşımın dar anlamda devlet merkezciliğinden uzaklaşırlar. Gerçekçilikten ayrı̧̧ıkları başlıca nokta ise araştırma yöntemi ve perspektifi konusundadır. Gerçekçi yazarlardan farklı olarak Renouvin ve Duroselle'in temel amaçları uluslararası ilişkilerin tarihsel açıdan incelenmesine katkıda bulunmaktır. ${ }^{38}$ Amerikan uluslararası ilişkiler literatüründe ya da Raymond Aron'un eserinde "uluslararası ilişkiler bilimi”ne katkıda bulunma kaygısının ağır basmasına rağmen tarihsel olgularla yeterince bağ kurulmadığına dair tespitleri de bu amacı belirginleştirir. Yazarlara göre yerleşik uluslararası ilişkiler literatüründe tarihsel örnekler yalnızca -hâlihazırda oluşmuş olan- kuramsal fikirlere bir temel oluşturması için verilmektedir. Renouvin ve Duroselle ise tarihi çıkış noktası olarak alıp, geçmişin belgelerinden yola çıarak gözlemlerini geliştirmeyi tercih ederler. $^{39}$

Introduction à l'bistoire des relations internationales'in Renouvin tarafindan yaz1lan ilk bölümü "Dipteki kuvvetler” başlığını, Duroselle’in yazdığı bölüm ise "Devlet Adamı” başlı̆̆ını taşır. Renouvin, “dipteki kuvvetler” kategorisi altında sırasıyla coğrafi faktörler, demografik şartlar, iktisadi güçler, finansal sorunlar, ulusal duygu, milliyetçilikler ve barış yanlısı duygu kategorilerini inceler. Kitabın sonuç kısmında ise siyasal ve yapısal faktörler çeşitliliğinden yola çıkarak 19. yüzyıl sonu ve 20. yüzyıl başındaki kolonyal yayılmanın ve dünya savaşlarının nedenlerinin kısa bir incelemesini yaparlar. Eserin sonunda vardıkları sonuç açıktır: Uluslararası ilişkiler incelemeleri yapan tarihçiler araştırmalarına başlarken belirli bir faktöre öncelik vererek o faktörün diğerleri üzerine belirleyici olduğu önvarsayımından hareket etmek yerine uluslararası ilişkilerin oluşumunda tüm faktörlerin etkili olabileceği fikrinden yola çıkarlarsa tatmin edici sonuçlara varabilirler. ${ }^{40}$

Kitapta her iki yazarın da inceledikleri faktörleri tüm ayrıntılarıyla ele alma kaygısını taşıdıkları görülür. Çok sayıda tarihsel örnekten yola çıkarak incelemelerini yaparlar, ancak seçtikleri örneklerin çok büyük bir kısmının uzmanlık alanları olan dönemden (1870’lerden 1940'lara uzanan zaman diliminden) alındığı görülür. Coğrafi açıdan ise verilen örneklerin önemli bir kısmı Avrupa ülkelerinin tarihiyle bağlantılıdır, buna karşılık ulus ve ulusçuluk gibi kavramları ele aldıkları bölümlerde Avrupa dışı örnekleri de yoğun olarak kullanırlar.

Renouvin ve Duroselle'in kitabına (özellikle de Renouvin'in yazdığı ilk bölüme) hâkim olan motif, belirlenimciliğin reddidir. Yazarlar, uluslararası ilişkilerde tek bir faktörü yalıtarak bu faktörün diğer faktörler üzerinde belirleyici olduğunu öne süren anlayışları red-

38 Ibid., s.3.

39 Ibid., s.3-4.

40 Ibid., s.454. 
dederler. Örneğin Friedrich Ratzel’in coğrafya ve politika arasındaki ilişkiler üzerine yaptığı çalışmalar uluslararası ilişkiler için önem taşısa da, Ratzel'in takipçilerinin toprak genişletme isteğinin önemi gibi çeşitli stratejilere mutlak bir önem atfetmesi bilimsel açıdan kabul edilemez. Coğrafya uluslararası ilişkilerin önemli bir unsurudur, ancak belirleyici bir niteliği yoktur. ${ }^{41}$ Aynı şekilde demografik belirlenimcilikten yola çıkan yaklaşımları da reddederler; örneğin kalabalık bir nüfus, bir devletin güçlenmesi için kendi başına yeterli bir şart değildir. Uluslararası ilişkilerin demografik boyutları incelenirken, salt insan sayısından başka faktörler de dikkate alınmalıdır. Örneğin tarımsal nüfusun genel nüfusa oranı ya da devletin nüfus politikaları gibi unsurlar demografinin siyaset üzerindeki etkisini değiştirebilecek unsurlardır; demografik güçler iktisadi, siyasal ve psikolojik bağlam dışında incelenemez. ${ }^{42}$ Aynı şekilde iktisadi faktörü de yalıtılmış olarak incelemek mümkün değildir, her özel durumda iktisat politikaları ve siyasal eylemlerin birbirlerinin üzerinde nasıl etkili olduğu (ya da birbirlerini nasıl kullandığı) ayrıntılı olarak incelenmelidir. Renouvin, iktisadi anlaşmaların her zaman uluslararası barışı korumayı sağladığı yönündeki tezlere de kuşkuyla yaklaşır, keza bu anlaşmalar çoğunlukla iktisadi çıkarlar doğrultusunda yapılmaktadır. Dolayısıyla iktisadi ilişkilerin iyileşmesinin barışı sağlaması yönünde bir teminat yoktur. ${ }^{43}$ Ulusal kavramının da değişken bir tanıma sahip olduğu ve mutlaklıktan uzak olduğunu vurgular. ${ }^{44}$

Kitabın ikinci bölümünde, Duroselle "devlet adamı"nı çeşitli boyutlarıla inceler. Yazar öncelikle insan karakterinin karmaşık bir yapıda olduğunu ve çok çeşitli karakter tiplerinin var olduğunu belirtir. Dolayısıyla belirli bir insan doğası ya da insan karakteri modelini temel almak yerine kitabın geri kalan kısmında olduğu gibi "karmaşıklık"a atıf yaparak incelemesini başlatır. "Ulusal çıkar" kavramını da devlet adamı konusuyla bağlant1lı olarak inceler. Duroselle'e göre demokratik kurumların ortaya çıkmasıyla "hükümdar çıkarı" yerine "ulusal çıkar" kavramı ön plana çıkmıştır, ancak genel, nesnel bir ulusal çıkardan söz etmek mümkün değildir, zira her toplum sınıflara ve çıkar gruplarına bölünmüş durumdadır ve bu sınıf ve grupların çıkarları çoğunlukla farklı, hatta çelişiktir. ${ }^{45}$ Duroselle, "devlet adamı" ile "dipteki kuvvetler" arasındaki ilişkilere de özel bir önem atfeder. Dipteki kuvvetler devlet adamı üzerine dolaylı bir etki uygulayabilir, devlet adamını yönlendirebilir, ya da bazen doğrudan bir toplumsal baskı haline bürünebilir. Buna karşıllk devlet adamı da dipteki kuvvetler üzerine etki eder, iktisadi-toplumsal güçler ya da kolektif psikoloji unsurları üzerine değişiklik yapabilir, onları yönlendirebilir. ${ }^{46}$

Tek yönlü belirlenimleri ve belirli bir faktörün belirleyiciliğini reddeden bu yaklaşımın vardığı genel sonuç, uluslararası ilişkilerde büyük genellemelerin ve genel kanun arayışının eleştirisidir. Tarihsel açıklamanın değer taşıyan sonuçlar elde etmesi için ön şart, genel bir açıklamaya ulaşmaya çabalamak yerine belirli vakaları incelemekle yetinmektir. Dolayısıyla Renouvin ve Duroselle'e göre tarih incelemelerinde genel kanunlara ulaşma

41 Ibid., s.23-24, 27.

42 Ibid., s.38-39, 41, 65.

43 Ibid., s.105,124.

44 Ibid., s.170.

45 Ibid., s.314-316.

46 Ibid., s.355, 383-384. 
çabası yersizdir. ${ }^{47}$ Yazarlar bu şekilde bir yandan soyut kuramları mutlaklaştıran yaklaşımları aşmaya çabalamakta, diğer yandan da olgusal-ampirik verilere mutlak bir önem atfeden tarih yaklaşımlarını aşarak kuramsal genelleme ve tarihsel olgular arasında bir diyalektik ilişki kurmaya çabalamaktadırlar. Buna karşılık, devlet adamına son kertede özel bir önem atfetmeleri yazarların tam anlamıyla bir bütünsel tarih yaklaşımı geliştirmelerini ya da maddi üretim süreçleri, ideolojiler ve uluslararası ilişkiler arasındaki bağlantıları karmaşıklıkları içinde incelemelerini engellemiştir.

\section{Uluslararası İlişkilerde Renouvin Ekolü}

\section{Duroselle’in Uluslararası İlişkiler Kuramı: "Her Imparatorluk Yok Olacaktır”}

Renouvin'in 1964'te emekli olmasından sonra Duroselle Sorbonne'daki yakınçăg tarihi kürsüsünü devraldı. Renouvin emeklilik döneminde de yayın yapmaya ve tez jürilerinde yer almaya devam etti, örneğin Birinci Dünya Savaşı üzerine bir sentez niteliğindeki kitabı 1965 tarihinde yayımlandı. ${ }^{48}$ Renouvin'in öldüğü 1974 tarihinde Duroselle’in, öğrencilerinin ve bir grup İsviçreli tarihçinin girişimiyle Relations Internationales (Uluslararası İlişkiler) dergisi çıkarılmaya başladı; bu dergi uluslararası ilişkiler tarihine Renouvin'in çizdiği çerçeveden katkıda bulunan yazıların yayınlandığ 1 bir mecra haline geldi.

Duroselle 1960'larda ve 1970'lerde yayımlanan çalısmalarında olgu tahlilinin önemine dikkat çekmeye devam etti. Yazara göre geçmişin olgularını yeniden kurmak, olguların dizilimini anlaşılır kılmak tarihçinin hakikat arayışındaki önemli adımlardır. Duroselle, olguları bilmeden onları yorumlayanlara karşı okuyucularını uyarır; buna karşılık, olguları bilmekle yetinen ve onları anlamaktan, açıklamaktan uzak duranları da eleştirir. Duroselle'e göre "tarih tektir ve bütünseldir"; olgular "toplumsal”, "iktisadi", "siyasal” gibi çeşitli kategorilere ayrilabilir, ancak "toplumsal tarih”, "iktisat tarihi”, "siyasal tarih” gibi mutlak olarak birbirinden ayrılan alanlar yoktur; farklı olguların dizilimi bütün ile açıklanır. ${ }^{49}$

Duroselle'in Tout empire périra (Her İmparatorluk Yok Olacaktır) başlıklı kitabının ilk baskısı 1981'de yayımland $1 .{ }^{50}$ Duroselle, kitabın giriş kısmında bilim insanı ve tarihçinin gerçekliğe yaklaşımları arasında bir ayrım yapar. Bilim insanı fenomenleri inceler; fenomenler doğrudan doğruya ya da dolaylı olarak insanın duyularıyla algılanır, temelde zamandan bağımsızdır. Tarihçinin incelediği olaylar ise belirli bir tarihte gerçekleşmiştir, benzeri yoktur. Tarihsel incelemenin konusu belirli bir olaylar kategorisinin sebep-sonuç bağlantısıdır. ${ }^{51}$ Duroselle, bu genel tanımları yaptıktan sonra uluslararası ilişkiler bilimi

47 Ibid., s.169.

48 Renouvin, Pierre, La Première Guerre mondiale, Paris, Presses Universitaires de France, 1965 [1998].

49 Duroselle, Jean-Baptiste, L'Europe de 1815 à nos jours, Paris, PUF, [1964] 2002, s. 415.

50 Jean-Baptiste Duroselle, Tout empire périra: Théorie des relations internationales, Paris: Armand Colin, 1992.

51 Ibid., s.19. 
yapma çabasında olan ve bu çaba çerçevesinde tarihsel olaylarının karmaşıllı̆̆ının yerine soyut modellerden yola çıkmanın yeterli olduğunu düşünen, tarihsel olaylardan yola ç1kmayan, hatta tarih üzerine kitaplar okuma gereği duymayan bazı uzmanları eleştirir. ${ }^{52}$ Yazarın sunduğu tarihten temel alan kuram, somut olaylar üzerine kurulu olduğu ölçüde ampirik, bu olayların dizilimine dayandığı ölçüde evrimsel, olaylar arasındaki benzerlikleri ve bu olayların düzenli bir şekilde ortaya çıkmasını incelediği ölçüde yöntemseldir. ${ }^{53}$

Duroselle'in kitabının başlarında "yabancı" kavramının tahlili önemli bir yer tutar. Uluslararası ilişkiler incelemesinin çıkış noktası olarak "yabancı"yı alması, uluslararası ilişkileri en temel unsurlardan başlayarak kavramaya çabaladığını gösterir; ona göre uluslararası ilişkiler, birbirine dişsal, birbirinden farklı olan öznelerin ilişkileridir, bu farklılı̆̆ın temeli ise en temel insani ilişkilerde aranmalıdır. Yabancı, düşman olmasa da "farklı" olandır; farklılık ırk, dil, din gibi unsurlardan kaynaklanabilir. ${ }^{54}$ Duroselle çeşitli "yabancı"lık biçimlerini inceledikten sonra bir uluslararası ilişkiler tanımı yapar: "Uluslararası ilişkiler, -bireysel ya da kolektif- bir tarafin diğerine 'yabancı' olduğu olaylar bütünüdür." ${ }^{55}$ Yazar bu noktadan sonra dış ve iç politika arasındaki ayrımı inceler ve her dış politika eyleminin aynı zamanda bir iç boyutu olduğunun altını çizer. Buna karşılık, dış politika boyutu taşımayan iç politika olayları mevcuttur. ${ }^{56}$ Buna bağlı olarak, Duroselle'e göre her uluslararası kuramın derinlemesine bir iç politika incelemesi içermesi kaçınılmazdır. ${ }^{57}$

Duroselle, devletin incelemesine insan topluluklarının incelemesinden başlar. $\mathrm{Bu}$ çerçevede küçük ölçekli insan grupları, ara topluluklar (örneğin gündelik hayatta belirli durumlarda ya da belirli amaçlar doğrultusunda bir araya gelen insan toplulukları ya da sendikalar, ordu gibi örgütlü topluluklar), devlet ve çokuluslu topluluklar olmak üzere dört örgütlenme düzeyi tespit eder. Uluslararası sistemin dört boyutunu ayrıntılarılya inceledikten sonra, her uluslararası ilişkiler olayının iki veriye bağlı olduğunu söyler. Bunlar amaçsallık (finalité) ve nedenselliktir (causalité). Amaçsallı, insanların, toplulukların ve siyasal birimlerin geleceğe yönelik hesaplarının toplamıdır. Nedensellik ise uluslararası ilişkiler üzerinde etkili olan faktörlerdir. Bu ikili ayrım, Renouvin ve Duroselle'in 1964 tarihli kitaplarında yaptıkları ikili ayrımı ("dipteki kuvvetler" ve "devlet adamı" ikiliğini) anımsatır. Amaçsallık, uluslararası ilişkiler faillerinin (örneğin diplomatların, üst düzey askeri bürokrasinin, özellikle de bir topluluğun liderinin) geleceğe yönelik kurgusu ve tercihleriyle ilintilidir; ${ }^{58}$ bu tercihlerde taktik seçimler, istihbarat ve stratejik hesaplar çeşitli boyutlarda rol oynayabilir. Duroselle "nedensellik" kavramını açıklarken ise "güçler" terimine başvurur ve gerek doğal olayları, gerekse insan kitlelerini "güçler" olarak tanımlayarak Pierre Renouvin'in "dipteki kuvvetler” üzerine kuramını anımsatan yorumlar yapar.

52 Ibid., s.20-21.

53 Ibid., s.33.

54 Ibid., s. 42 .

55 Ibid., s.46.

56 Ibid., s.46-47.

57 Ibid., s.48.

58 Ibid., s.77. 
Güçler kategorisi “doğal güçler”i içerir, ancak güç temelde bir kollektiviteden kaynaklanır ve bir bilinçlenmeye bağlıdır. ${ }^{99}$ "Dipteki kuvvetler" kavramı da bu noktada devreye girer: Duroselle’e göre "dipteki kuvvetler”, örgütlü ve belirgin olan güçlerden farklı olarak, siyasal gelişmelerin temelinde yer alır.

Duroselle, önceki eserlerinde olduğu gibi kuramsal incelemelerde tarihsel perspektifin taşıdığı önemi vurgular; gerek barış̧̧ıl ilişkileri, gerekse çatışma ilişkilerini devletlerin yapısına ya da insan doğasına içkin özelliklerin dışavurumu olarak değil, tarihsel değişimin ve dinamiklerin sonucu olarak inceler. Bu açıdan, uluslararası ilişkilere klasik Gerçekçi ya da klasik liberal yaklaşımlardan farklı bir inceleme paradigması geliştirir. Savaşların yeni savaşlara neden olduğunu ve kalıcı bir barışın sağlanmasının mümkün olmadığını belirtirken de özsel, doğal önkabullerden hareket etmemekte, insan ilişkilerinde uzlaşmanın nadiren ortaya çıktığından yola çıkmaktadır. ${ }^{60}$

Duroselle bu şekilde uluslararası ilişkilerin statik ve dinamik unsurlarını inceledikten sonra kurama ulaşır. Başka bir deyişle, yazar uluslararası ilişkilerin çeşitli unsurlarından yola çıkarak kurama ulaşma yolunu tercih etmekte, özelden genele ulaşma yöntemiyle tarih yazımı yöntemine sadık kalmaktadır. Dolayısıyla kitabın gerçek anlamda kurama ilişkin bölümü kitabın son kısmıyla sınırlıdır. Bu kısımda Marksizm-Leninizm'den başlayarak uluslararası ilişkileri tekçi açıdan inceleyen basitleştirici kuramları eleştirir. Eleştirdiği kuramların arasında yalnızca iktisadi boyuta öncelik vermesini eleştirdiği Marksizm değil; bilinçdışına, rasyonel seçimlere, güç istencine ve değerlere dayanan kuramlar da bulunur. ${ }^{61}$ Yazara göre tarihsel olayların incelenmesinde ampirizmin önemli bir yeri olmak zorundadır, zira mutlak genellemeler yapmak imkânsızdır. ${ }^{62}$

Kitabın beşinci ve son bölümünün başlığı uluslararası ilişkiler kuramı olmakla birlikte, kısalığı dikkat çekicidir. Kuram bölümü esas olarak iki konu üzerine yoğunlaşır. Bunların ilki, kuram düzeylerine ilişkindir. Duroselle, üç kuramlaştırma düzeyi tespit eder. İnsanlık tarihinin genelinde bazı olayların gösterdiği benzerliklerin incelenmesi "düzenlilikler" (régularités) boyutunu teşkil eder; bu düzlemde teknolojik gelişmeler, uzun süreli değerler, insan toplulukları gibi unsurlar bu düzlemin içinde yer alır. Belirli tarihsel dönemlere sınırlı ve belirli bir coğrafi düzlemde ortaya çıkan unsurlar "zamansal kurallar" (règles temporaires) boyutunun parçasıdır; örneğin modern devlet belirli bir tarihsel dönemin ürünü olduğu için ikinci boyutun bir parçasıdır. Kısa vadede, şimdiki zamanda ortaya çıkan sorunlar ise üçüncü düzlemi oluşturur; Duroselle bu düzleme "reçeteler" (recettes) düzlemi adını verir, zira araştırmacıların kendi dönemlerinde olan olayları bilimsel olarak inceleme imkânı olmadığından bu olaylara ilişkin tavır geliştirirken geleceğe yönelik politika tavsiyeleri vermekle yetinmek zorundadırlar. ${ }^{63}$

$\overline{59 \text { Ibid., s.125-126. }}$

60 Ibid., s.251.

61 Ibid., s.257.

62 Ibid., s.259-260.

63 Ibid., s.261-277. 
Duroselle'in kitabının son kısımlarında incelediği "imparatorluk" kavramı ise yazarın "büyük güçler", "süper güçler", "dünya gücü" gibi kavramlara alternatif olarak kullandığı bir kavramdır. İmparatorluklar, fatihlerin kurduğu kısa ömürlü siyasal yapılardan hanedan siyasal yapilarına, kolonyal imparatorluklardan (deniz imparatorluklarından) "ekonomik emperyalizm”e uzanan geniş bir yelpazedeki çeşitli siyasal iktidar biçimlerini incelemek için kullandığı bir genel kavramdır. Kitap 1981 yılında, Sovyet Sosyalist Cumhuriyetler Birliği'nin henüz dağılmadığı bir dönemde yazıldığından, Duroselle bu ülkeyi "imparatorluk" kavramı çerçevesinde değerlendirmeye özel bir önem atfeder; yazara göre "Sovyet İmparatorluğu" özellikle içsel nedenlerle yıkılması kaçınılmaz olan imparatorluklardan biridir; örneğin Sovyetler Birliği’nin topraksal yayılma stratejisine bağlı olarak imparatorluk siyaseti izlediğini savunur. Amerika Birleşik Devletleri'nin ise topraksal bir emperyalizm uygulamak yerine esas olarak iktisadi bir etki alanı yaratt1ğ1 söyler ve tam anlamıyla bir imparatorluk olarak değerlendirilemeyeceğini savunur. ${ }^{64}$ Aynı şekilde Çin de bir yayılma politikası izlemediğinden bir imparatorluk değildir. Yazar, gelecekte yeni imparatorlukların ortaya çıkabileceğini (ya da var olan güçlerden birinin imparatorluk haline gelebileceğini belirtir, ancak geçmişteki tüm diğer imparatorluklar gibi yeni imparatorlukların da içsel ya da dişsal faktörlerin sonucu olarak ortadan kaybolacağını savunur. ${ }^{65}$

Duroselle, bu kitapta olduğu gibi başka yazılarında da basit soyutlamalar yapmanın kolaylığına dikkat çeker. Oysa somut tahliller yapılırsa siyasal gerçeklik çok daha temelli bir şekilde anlaşılabilir. Örneğin siyasette ve uluslararası ilişkilerde "büyük sermaye" gibi genel, var olduğu varsayılan kategorilerin etkin olduğu varsayımından yola çıkılarak tahliller yapmak yerine belirli kişi ve grupların faaliyetleri temel alınmalı, küçük ve somut grupların siyasetteki gerçek etkileri araştırılmalıdır. Bu, Duroselle'e göre yeni bir yöntemdir ve küçük grupların incelenmesini temel alır, bu şekilde olaylar ve kuramsallaştırma arasında bağlantı kurulur. ${ }^{66}$

Duroselle'in Tout empire périra başl1klı kitabı ve 1980'lerin başından itibaren kaleme aldığı diğer çalışmalar bir bütün olarak incelendiğinde, Renouvin’in uluslararası ilişkiler üzerine çalışmalarında sık sık sorunsallaştırılan olgu-kuram ilişkisinin yine ön planda olduğu görülür. Duroselle doğrudan doğruya uluslararası ilişkiler kuramına katkı yapmaya çalıştığı bu kitapta bile tam anlamıyla bir tarihçinin çalışma yöntemiyle inceleme yapmaktadır. Bu yöntemin uluslararası ilişkiler literatürüne başlıca katkısı, kuramsal çalışmalarda sıklıkla kullanılan "güç", "imparatorluk" gibi kavramları somut tarihsel gerçeklikteki izdüşümlerini değerlendirerek anlamlandırmasıdır. Bu şekilde sabit tutulan kavramlar üzerinden modellemeler yapmak yerine kavramları toplumsal-siyasal izdüşümleri üzerinden inceler ve uluslararası ilişkilerin tarihsel süreç içindeki gelişimini karmaşıklığıyla yansıtmaya çabalar.

64 Ibid., s.298-299, 310-311.

65 Ibid., s.312.

66 Jean-Baptiste Duroselle, Itinéraires: idées, hommes et nations d'Occident, XIXe-XXe siècles, Paris, Publications de la Sorbonne, 1992, s.99. 


\section{René Girault ve "Halklararası İlişkiler Taribi"}

Renouvin ve Duroselle'in Sorbonne'daki çabalarına ve faaliyetlerine rağmen "uluslararası ilişkiler tarihi” adını taşıyan bir kürsünün açılması Paris X Nanterre Üniversitesi’nde mümkün oldu. 1973 yılında açılan bu kürsünün başında Renouvin ile Duroselle'in öğrencisi olmuş olan René Girault bulunuyordu. ${ }^{67}$ Girault'nun uluslararası ilişkiler tanımı Renouvin ve Duroselle'in tanımından da daha geniştir. Girault “tarih”i geçmiş insan eylemlerinin yeniden kurulması ve açıklanması olarak tanımlar. Uluslararası ilişkiler tarihinin alanını ise devletler arası ilişkilerle bağlantılı olduğu ölçüde siyasal, iktisadi, kültürel, toplumsal, ideolojik, etnik faaliyetlere genişletir. Aynı zamanda uluslararası ilişkiler tarihini "sınırlar tarafından ayrılan insanların arasındaki ilişkiler” tarihi ${ }^{68}$ olarak tanımlayarak selefleri Renouvin ve Duroselle'e kıyasla devlet merkezlilikten uzaklaşan bir yönelime girer. Bu şekilde, öğrencisi Robert Frank'ın deyişiyle, "halklar arası ilişkiler tarihçisi” olarak nitelenebilir. ${ }^{69}$

Duroselle'in emekliliğinden sonra Paris I Panthéon-Sorbonne Üniversitesi'ndeki kürsüyü devralan Girault'nun girişimiyle söz konusu üniversitenin bünyesinde 1983 yılında Pierre Renouvin Enstitüsü kuruldu. Enstitü, 1935'ten beri Sorbonne'da faaliyet gösteren araştırma grubunun kurumsallaşmış hali olarak değerlendirilebilir. ${ }^{70}$ Girault, öğrencisi ve halefi Robert Frank'ın da belirttiği gibi, Renouvin ve Duroselle'e benzer şekilde eğitim ve araştırmayı birbirinden ayrılmaz faaliyetler olarak düşünmüş ve genç araştırmalar yetiştirmeye özel bir önem atfetmiştir. ${ }^{71}$

Girault 1985 tarihli bir makalesine "Tarihçi kendi zamanının tutsağıdır. Geçmiş üzerinde yaptığı sorgulamalar kişisel hayatının şartlarından ve kültürel çevresinde baskın olan reflekslerden etkilenir.” sözleriyle başlar. ${ }^{72}$ Girault bu şekilde pozitivist tarihçilerin tarihi mutlak doğruyu yansıtan bir disiplin olarak ele alan yaklaşımlarını eleştirir. Girault'nun bu yöntemsel konumlanı̧̧ı, Edward H. Carr'ın What is History? (Tarih Nedir?) kitabında ortaya koyduğu, tarihsel bilginin göreliliği ve tarih yazımının taraflılığını temel alan yaklaşımla ${ }^{73}$ kıyaslanabilir. Girault'ya göre 19. yüzyılın pozitivist tarihçileri geçmişteki olayların tasviri konusunda önemli bilimsel aşamalar kaydetmişlerse de "eski zaman insanlarının eylemlerinin sebeplerini anlama ihtiyacı"na yanıt verememişlerdir. ${ }^{74}$ Uluslararası ilişkiler alanındaki araştırmanın esas alanı devletler arası ilişkiler olmaya devam eder, iktisat tarihi yöntemlerine başvuran uluslararası ilişkiler tarihçileri bu hususu göz önünde bulundurmalı ve devletlerin önemini göz ardı eden çalışmalar yapmamalıdırlar. ${ }^{75}$

67 René Girault, "Souvenirs et pratiques”, Être historien des relations internationales içinde, Paris, Publications de la Sorbonne, 1998, s. 22-23. Ayrıca bkz. Robert Frank, "Hommage à René Girault", Bulletin de l'Institut Pierre Renouvin, No.8, 1999, s.21.

68 Girault, Diplomatie européenne: Nations et impérialisme, 1871-1914, s.1.

69 Frank, "Hommage à René Girault", s.19.

70 Duroselle, Tout empire périra, s.14-15.

71 Frank, "Hommage à René Girault", s.21.

72 Girault, "Le difficile mariage de deux histoires", s.37.

73 E. H.Carr, What is History?, Cambridge, Cambridge University Press, 1961.

74 René Girault, "Limaginaire et l'histoire des relations internationales", Être historien des relations internationales içinde, Paris, Publications de la Sorbonne, [1983] 1998, s.131.

75 Girault, "Le difficile mariage de deux histoires", s.52. 
Girault, 1970'lerin sonundan itibaren Yakınçağ'da Uluslararası İlişkiler konusunda bir sentez yapma çabasına girmiştir. Bu çabanın sonucu olan üç cilt sırasıyla 1979, 1988 ve 1993 yıllarında yayımlanmıştır. Girault bu çalışmanın ilk cildinin giriş kısmında uluslararası ilişkileri geniş bir inceleme alanı olarak tanımladıktan sonra uluslararası ilişkiler tahlilinin günümüzde geçerli kanunlar öne sürmek gibi bir hedefi olmadığını, meydana gelmiş olanın açıklamasıyla yetindiğini belirtir. ${ }^{76}$ Girault'nun bir diğer vurgusu, uluslararası ilişkiler tarihinin bütünsel niteliği üzerinedir. Yazara göre, sınırlarla ayrılan insanlar arasındaki her türlü ilişki uluslararası ilişkiler disiplininin konusunu teşkil eder. Dolayısıyla gerçek anlamda bir uluslararası ilişkiler incelemesi yapmak için iktisat, finans gibi pek çok alan, disiplin ve bilimin kesişiminden yola çımak gerekir. ${ }^{77}$

Girault'nun 20. yüzyıl tarihi (özellikle de İkinci Dünya Savaşı sonrası dönem) üzerine incelemelerinde ortaya çıkan unsurlardan biri, Avrupa sınırlarını aşan bir uluslararası ilişkiler tarihi yazımının imkânları sorunsalıdır. Girault'ya göre uluslararası ilişkiler tarihi dünya tarihi ile karışabilir, özellikle de "insanlar arası ilişkilerin artan oranda küreselleşmesi" geniş bir bakış açısından inceleme yapılması; farklı devletlerin, halkların ve kültürlerin arasındaki karmaşı ilişkilerin tahlil edilmesini gerektirmektedir. ${ }^{78}$ Buna bağlı olarak, dünyanın "Batı" dışında kalan kesimlerinin de incelemeye dâhil edilmesi gerekir. "Üçüncü dünya” sadece kolonizasyon bağlamında inceleme konusu olmaktan çıkmalı, kendisi için, kendinde bir inceleme alanı haline gelmelidir. ${ }^{79}$

Girault'nun (ve çalışma arkadaşları Robert Frank ile Jacques Thobie'nin) kitaplarda genel olarak kullandığı yöntem, olayların incelemesini yapmaktan kaçınmayarak olayların ötesine geçmeye ve derin bir dönüşüm süreci içindeki uluslararası yaşamın çeşitli dalgalanmalarını açıklayan genel güç çizgilerini anlamaya çabalamaktır. ${ }^{80}$

Yakınçağ'da Uluslararası İliskiler Taribi dizisinin son kitabı, Girault, Frank ve Thobie'ye göre önceki iki ciltten farklı niteliktedir. İnceleme alanının 1941-1964 yılları arasındaki zaman dilimi olması, kitabın 1993 yılında yayımlandığı göz önünde bulundurulursa, bu çalışmaya "şimdiki zamanın tarihi” özelliği kazandırır. Kaldı ki tarihçi olmayan uluslararası ilişkiler uzmanları da şimdiki zamanı incelemektedirler. Bu durum, yakın tarih üzerine çalışan tarihçilerin çalışma yöntemlerini açıkça belirlemelerini gerektirir. ${ }^{81}$ Yazarlara göre tarihçi salt hikâye anlatısı düzlemini aşarak mümkün olduğu kadarıla eylemlerin kökenine ulaşmalıdır: "Tarih basit bir anlatı değildir, açıklamadır". ${ }^{82}$ Girault'nun 1983 tarihli bir yazısında da belirttiği gibi, "Tarihçinin hedefi geçmişi tasvir etmektir. Tasvir etmek yalnızca olguları mümkün olan en kesin şekliyle yeniden kurmak değildir,

76 Girault, Diplomatie européenne: Nations et impérialisme, 1871-1914, s.1.

77 Ibid., s.1.

78 René Girault ve Robert Frank, Histoire des relations internationales contemporaines: Tome 2. 1914-1941: Turbulente Europe et nouveaux mondes, Paris, Masson, 1988, s.9.

79 René Girault, Robert Frank ve Jacques Thobie, Histoire des relations internationales contemporaines: Tome 3: La loi des géans, 1941-1964, Paris, Masson, 1993, s.4.

80 Girault ve Frank, Histoire des relations internationales contemporaines: Tome 2: 1914-1941, s.14.

81 Girault, Frank ve Thobie, Histoire des relations internationales contemporaines: Tome 3, s.1.

82 Ibid., s.3. 
aynı zamanda bu geçmiş olguların nedenselliklerini açıklamaya çalışmaktır." ${ }^{33}$ Girault ve çalışma arkadaşları, olayların ve eylemlerin açıklamasını yaparken tekçi bir yönteme başvurmazlar, gerçekleri hâlihazırdaki teorilerle çerçevelemekten kaçınırlar. ${ }^{84} \mathrm{Bu}$ açılardan, Duroselle'in son dönem kuramsal çalışmalarında da belirttiği gibi, olaydan çıkarak kurama varmayı esas alan bir yöntem izlemeyi tercih ederler. Buna karşılık, bürokrasi tahlili ya da kamuoyu incelemeleri gibi konularda tarih dışındaki çeşitli disiplinlerin yöntemlerinden yararlanmanın gerekliliğinin de altını çizerler, örneğin tarihte kamuoyu incelemeleri konusunda siyaset bilimcilerin, sosyologların, etnologların, sözlük yazarlarının katkıları tarihçiler için önemlidir. ${ }^{85}$

René Girault, 1994'te emekliye ayrılmadan önce yaptığı bir konuşmada kuramlaştırmayı tarihçinin entelektüel birikiminin bir sonucu olarak gördüğünü belirtir. Başka bir deyişle, tarihçiler ancak belirli bir tarih pratiğinden hareketle araştırmalarının kuramını yapabilirler. ${ }^{86} \mathrm{Bu}$ genel tespitten sonra sorduğu başlica kuram sorusu ise iktisat ve siyasetin ilişkilenme biçimlerine ilişkindir. Gerek iktisat ve siyaset ilişkileri konusunda, gerekse kolektif düşüncelerin dış politikadaki etkisi konusunda Renouvin’in "dipteki kuvvetler" üzerine tezlerini tekrarlar. Girault'nun kurama katkı yapma çabalarında bir diğer uğrak da uluslararası ilişkileri kuramlaştırma hedefine uygun olarak bir dönemleme modeli ortaya koymaktır. Teknolojik, iktisadi, ideolojik, dini ve toplumsal şartların etkisi ve iç içe geçiş biçimleri açısından benzer özellikler gösteren dönemleri ayırt ederek uluslararası ilişkilere ilişkin genel bir açıklama getirilebileceğini savunur. ${ }^{87} \mathrm{Bu}$ genel tespitten sonra Girault kendi dönemleme modelini ortaya koyar, ancak bu çabayı 19. ve 20. yüzyıllarla sınırlı tutar. Girault'nun tespit ettiği dönemler (19. yüzyılın başından 1880’lere; 19. yüzyıl sonundan İkinci Dünya Savaşı'na; 1945'ten Sovyetler Birliği'nin dağılmasına; Sovyetler Birliğiinin dağılmasından günümüze) "kültürel aşama”lara tekabül eder. Girault'ya göre kültürel aşama (stade culturel) sınırlar tarafindan insanlar arasındaki ilişkileri karakterize eden nesnel verilerin bütününe ilişkin dönemsel algıları ifade eder. ${ }^{88}$ Başka bir deyişle, Girault'ya göre uluslararası ilişkiler tarihinin çeşitli dönemlerini ayırt etmemizi sağlayan, belirli bir siyasal üstünlüğün ya da iktisadi tahakkümün ortaya çıkması değil, nesnel verilerin bütününün şekilleniş biçimidir. Dolayısıyla siyasetçilerin etkinlik düzeyi, ulusun savunması gibi temalar ya da süper güç kavramının ortaya çıkışı uluslararası ilişkilerin tarih-ötesi, özsel özelliklerinden kaynaklanmaz, belirli tarihsel dönemlerde şekillenir ve bazı dönemlerde geri plana düşer ya da ortadan kaybolur. Görüldüğü gibi, Girault kuramlaştırma çabasında bile genellemelerden kaçınmakta ve tarihsel dönemlerin özgüllüğü konusunda ssrar etmektedir.

83 Girault, "Limaginaire et l'histoire des relations internationales", s.131.

84 Girault, Frank ve Thobie, Histoire des relations internationales contemporaines: Tome 3, s.3.

85 Ibid., s.4.

86 Girault, "Souvenirs et pratiques", s.15, 24.

87 Ibid., s.28.

88 Girault, René, "Souvenirs et pratiques”, s.28. 


\section{Sonuç}

Fransız uluslararası ilişkiler ekolünün genel özellikleri; kurumsal nitelik, mensuplarının benimsediği inceleme düzeyi, araştırma yöntemleri, soyutlama konusuna yaklaşımları ve geleceğe yönelik kestirimlere ilişkin olarak takındıkları tavır olmak üzere beş temel başlikta incelenebilir.

Kurumsal açıdan incelendiğinde, Fransız uluslararası ilişkiler tarihi ekolünün belirgin bir gelenek teşkil ettiği söylenebilir. Pierre Renouvin'in Paris Üniversitesi'nde, Sorbonne binasında yaptığı dersler, düzenlediği seminerler ve yönettiği doktora tezleriyle oluşan bir gelenek, söz konusu ekolün üniversite içi mekanizmaların getirdiği usta-çırak ilişkisine bağlı olarak konsolide olmasını sağlamıştır. Pierre Renouvin Enstitüsü’nün ve ona bağlı programların kurulmasıla ekolün kurumsallaşma süreci ivme kazanmıştır.

İnceleme düzlemi açısından, Fransız uluslararası ilişkiler tarihi ekolü mensupları devlet merkezli olmayan bir yaklaşım benimsemeye çalışsalar da devletin son aşamada belirleyici olduğundan hareket ederek tahlil yaparlar. Duroselle'in kimi eserlerinde devlet ve "karar alıcı"nın rolü "dipteki kuvvetler" kavramının bile ötesine geçerek belirleyici bir hal alabilir, Girault ise uluslararası ilişkilerin "halklar arası ilişkiler tarihi” olarak yeniden değerlendirilmesi gerektiğini savunur, ancak esas inceleme alanının devletler arası ilişkiler olduğunu söylemekten geri durmaz, keza sözü edilen "halklar" sınırların (dolayısıyla devlet sınırlarının) birbirinden ayırdığı halklardır.

Araştırma yöntemi açısından, Fransız uluslararası ilişkiler tarihi ekolü temsilcileri somuttan soyuta, özelden tikele ve genele ulaşan bir yaklaşım benimserler. Siyaset bilimi ve uluslararası ilişkiler uzmanlarının önemli bir kısmının kuramsal önkabullerle ve genellemelerle araştırmaya başlayıp seçmeci bir anlayışla önkabullerine uygun olgu bulmaya çalıştıklarını öne sürerler. Buna karşı benimsedikleri yöntem tarihsel araştırma yöntemidir: Araştırma sorularından ve hipotezlerden hareketle ve belgelerden yola çıkarak tarihsel olayları incelerler ve olgusal gerçekliğin karmaşıklığını (ve araştırmacının kısıtlarını) göz önünde bulundurarak belirli tarihsel bağlamlarda ve dönemlerde oluşan uluslararası ilişkiler üzerine sonuçlara varırlar.

Soyutlama ve kuramlaştırma açısından, Fransız uluslararası ilişiler ekolü uluslararası ilişkiler literatürüne sınırlı bir katkı sunmuştur. Duroselle, 1981 tarihli Tout empire périra (Her İmparatorluk Yok Olacaktır) başlıklı kitabında uluslararası ilişkileri bütünsel bir şekilde değerlendirmeye çalışır, ancak her türlü indirgemecilikten kaçındığ1 için uluslararası ilişkiler kuramı kitaplarından ziyade hukuk kitaplarını andıran ayrıntılılıkta bir çalışma ortaya koyar. Renouvin ve Girault'nun kuram çabaları ise çoğunlukla yöntemsel bir çerçeveyle sınırlı kalır. Ampirik çeşitlilik ve karmaşıklık genelleme ve kuramlaştırma çabalarının ötesine geçer. Yazarlara göre uluslararası ilişkiler incelemeleri için önemli olan, faktörlerin belirli bir dönemdeki ilişkilenme biçimleri ve bu ilişkilenmenin zamansal evrimidir.

Normatif açıdan incelendiğinde Fransız uluslararası ilişkiler ekolü geleceğe yönelik herhangi bir öngörüde bulunmaktan bilinçli olarak ve mutlak surette kaçınmakta- 
dır. Bu tavrın özellikle yöntemsel nedenleri vardır. Ekole mensup yazarların uluslararası ilişkilerde (ve genel olarak tarihte) genel kanunların ve basit belirlenimlerin varlığını reddetmeleri, tüm zamanlar için ve gelecek dönemler için geçerli bir açıklama aray1şına girmemeleri sonucunu doğurur. Tarihsel olayların her birinin kendi karmaşık nedensellik sistemi içinde anlam kazandığı dikkate alınırsa, şimdiki zamanda yer alan ve gelecekte meydana gelecek olan olayların da kendi özgül bağlamında bir nedenselliğe bağlı olarak şekilleneceği sonucuna varılabilir. Dolayısıyla gelecek için her türlü politik yönelimin meydana gelmesi mümkündür ve geleceğe yönelik öngörülerde ya da projeksiyonlarda bulunulması yersizdir. 


\section{Kaynakça}

Bourdé, Guy ve Martin, Hervé, Les écoles historiques, Paris, Seuil, 1990.

Carr, E. H., What is History?, Cambridge, Cambridge University Press, 1961.

Chabod, Federico, Storia della politica estera italiana dal 1870 al 1896, Bari, Laterza, 1997.

Depretto, Jean-Paul, “René Girault (1929-1999)”, Revue des études slaves, Cilt 71, No 3-4, 1999, s. 743-746.

Duroselle, Jean-Baptiste, Histoire diplomatique de 1919 à nos jours, Paris, Dalloz, [1953] 1993.

Duroselle, Jean-Baptiste, Itinéraires: idées, hommes et nations d'Occident, XIXe-XXe siècles, Paris, Publications de la Sorbonne, 1992.

Duroselle, Jean-Baptiste, L'Europe de 1815 à nos jours, Paris, PUF, 2002.

Duroselle, Jean-Baptiste, "Pierre Renouvin (1893-1974)", Revue d'Histoire moderne et contemporaine, Cilt 22, 1975, s. 497-507.

Duroselle, Jean-Baptiste, "Pierre Renouvin et la science politique", Revue française de science politique, Cilt 25, No 3, 1975, s. 561-574.

Duroselle, Jean-Baptiste, Tout empire périra: Théorie des relations internationales, Paris: Armand Colin, 1992.

Frank, Robert, "Hommage à René Girault", Bulletin de l'Institut Pierre Renouvin, No 8, 1999, s. 17-23.

Girault, René, Diplomatie européenne: Nations et impérialisme, 1871-1914, Paris, Armand Colin, [1979] 1997.

Girault, René, "Le difficile mariage de deux histoires: Économie et relations internationales dans le monde contemporain", Être bistorien des relations internationales içinde, Paris, Publications de la Sorbonne, [1985] 1998, s. 37-52.

Girault, René, "L'imaginaire et l'histoire des relations internationales", Etre bistorien des relations internationales içinde, Paris, Publications de la Sorbonne, [1983] 1998, s. 131-137.

Girault, René, "Pierre Renouvin, la BDIC et l'historiographie française des relations internationales”, Matériaux pour l'histoire de notre temps. No 49-50, 1998, s. 7-9.

Girault, René, "Souvenirs et pratiques", Être historien des relations internationales içinde, Paris, Publications de la Sorbonne, 1998, s. 15-33.

Girault, René ve Frank, Robert, Histoire des relations internationales contemporaines: Tome 2: 19141941: Turbulente Europe et nouveaux mondes, Paris, Masson, 1988.

Girault, René, Frank, Robert ve Thobie, Jacques, Histoire des relations internationales contemporaines: Tome 3: La loi des géans, 1941-1964, Paris, Masson, 1993.

Hoffmann, Stanley, "Compte rendu de la table ronde sur les fondements de la politique étrangère, 13-14 juin 1953", Duroselle, Jean-Baptiste (der.), La politique étrangère et ses fondements, Paris, Armand Colin, s. 374-402.

Jeannesson, Stanislas, "Diplomatie et politique étrangère de la France contemporaine: Un bilan historiographique depuis 1990", Histoire, économie Es société, Cilt 31, No 2012/2, s. 87-98.

Martel, André, “De la 'question d'Orient' aux affaires des Balkans ou du recours à l'histoire et de ses limites”, Jean-Robert Henry ve Gérard Groc (der.), Politiques méditerranéennes entre logiques étatiques et espace civil: Une réflexion franco-allemande, Paris, Karthala-IREMAM, s. 57-72.

Mayeur, Jean-Marie, "Pierre Renouvin et l'histoire religieuse", Revue d'histoire de l'Église de France, Cilt 63. No 170, 1977, s. 103-106.

Renouvin, Pierre, “Entretien avec Maurice Paléologue, le 12 février 1936”, Matériaux pour l’histoire de notre temps, No 47, 1997, s. 61-63.

Renouvin, Pierre, "Introduction générale”, Renouvin, Pierre (der.), Histoire des Relations internationales: I: Du Moyen Âge à 1789, Paris, Hachette, [1953] 1994, s. 7-13. 
Renouvin, Pierre, La crise européenne et la Première Guerre mondiale, Paris, PUF, 1962.

Renouvin, Pierre, La Première Guerre mondiale, Paris, Presses Universitaires de France, 1965 [1998].

Renouvin, Pierre, "La Presse et l'histoire", Matériaux pour l'histoire de notre temps, No 49-50, 1998, s. 83-88. [İlk basim: Revue de Synthèse historique, Cilt 33, No 97-99, 1921].

Renouvin, Pierre, "Research in Modern and Contemporary History: Present Trends in France", The Journal of Modern History, Cilt 38, No 1, 1966, s. 1-12.

Renouvin, Pierre ve Duroselle, Jean-Baptiste, Introduction à l'histoire des relations internationales, Paris, Armand Colin, [1964] 1970.

Roche, Jean-Jacques, "L'enseignement des relations internationales en France: Les aléas d'une 'discipline-carrefour", Revue internationale et stratégique, No 47, 2002, s. 100-107. 


\section{Summary}

During the late 19th and early 20th century, the historiography of international relations was dominated by a state-centric approach that gave predominance to the description of political events, diplomatic relations and decision-making process. However, the approach of "diplomatic history" has been widely criticized since the beginning of the 20th century, and alternative approaches emerged. In contemporary historiography, the research field of the discipline of history of international relations is extended from a merely state-centered approach to a broader approach combining political history with social, economic and cultural history. This change of scope and methodology affected even the names given to the discipline: "Diplomatic history" textbooks are growingly replaced by books on "international history", or "history of international relations", reflecting the search for a total history of international relations instead of a specifically political-diplomatic history. The present paper analyzes the main characteristics of a modern school of historiography of international relations - the "French school of the history of international relations", or the "French school of international relations", founded by the French historian Pierre Renouvin in the aftermath of the First World War, and developed by his students.

The present paper analyzes the contribution of Renouvin and of his followers (Jean-Baptiste Duroselle and René Girault amongst others) to the reinterpretation of the history of international relations. After an analysis of the concept of "profound forces" developed by Renouvin, it tackles the publications by Renouvin and Duroselle regarding the methodology of international relations. According to the authors, not only the state and the statesman, but also "profound forces", that is, geographic, economic and social factors as well as collective psychology play an important role in the shaping of international events and facts. The last part of the article covers research activities undertaken by the followers of Renouvin, syntheses they published since the mid-1970s, and their attempts at institutionalization of the French school of international relations. The article also seeks at investigating the relationship and methodological differences between the fields of history, political science, and international relations, as conceived by the members of the "French School".

From an institutional point of view, the French school of the historiography of international relations consists of a distinct tradition. The courses held by Pierre Renouvin at the University of Paris (Sorbonne), the seminars he organized and the dissertations he supervised inaugurated a certain tradition, which evolved into a tradition that became consolidated in the subsequent years within a master-apprentice relationship. The foundation of the Pierre Renouvin Institute at Sorbonne and the launching of the graduate programs linked with that institute contributed to the institutionalization of the school.

Regarding the level of analysis of international relations, the members of the French school attempt at adopting an approach that rejects state-centrism. However, their approach implies an approach in which inter-state relations are predominant in the last stance. In the Duroselle's Works, the role of the state and of the "decision-maker" can become even more predominant. Girault, while he opts for a redefinition of international relations as "relations between peoples", still defines the main field of study of international relations as the inter-state relations, as the "peoples" in question are peoples "separated by (state) borders".

As for the research methods, the members of the French school of the history of international relations adopt an approach that consists of reaching the general conclusions through the analysis of specific cases. They accuse scholars of political science and international relations for starting research with theoretical assumptions and generalizations, and for trying to search for appropriate historical facts with a selective approach to history. Instead, they adopt historical research method: They depart from research questions and hypotheses, analyze historical events through 
primary sources, and reach conclusions on the international relations in specific contexts and periods, taking into consideration the complexity of reality, as well as the limitations of the researchers.

From the point of view of theorization, the French school's contribution to the field of international relations is limited. If Duroselle makes an attempt at developing a total analysis of international relations in his 1981 book Tout empire périra (Each Empire Will Perish), he still avoids any determinism, hence the similarity of the aforementioned book with law treatises rather than with books on the theory of international relations. The attempts of Renouvin and Girault to create a theory of international relations are limited to contributions to the methodological framework of the history of international relations. Empirical diversity and complexity prevents, for the authors in question, any attempt at generalization and theorization. According to the authors, what counts for an appropriate study of international relation is the study of the configuration of diverse factors in a specific period, and of the temporal evolution of these configurations.

Regarding normative aspects theory, the French school consciously and categorically rejects any prevision towards the future. This attitude has mainly methodological sources. The fact that the members of the French school reject the existence of general laws and simple, unilateral determinations in international relations (and, generally speaking, in history) results in their denial of a search for an explanation that would be valid for all times and for the future. If historical events can be explained in a specific and proper system of complex causality, it can be concluded that the events of the present and of the future can be considered as linked to a specific, unique causality. For this reason, they assert that the evolution of the factors and causalities can create different political orientations and events, and it is impossible to foresee the future. 